\title{
PRELIMINARY REPORT OF A FORECAST SYSTEM TESTED IN QUINCE TO PREDICT FIRE BLIGHT SYMPTOM OCCURRENCE
}

\author{
János ÁGOSTON ${ }^{1 *}$ \\ 1 John von Neumann University, Faulty of Horticulture and Rural Development, Department of Agriculture. \\ 6000 Kecskemét, Mészöly Gyula tér 1-3. Hungary \\ https://doi.org/10.47833/2020.2.AGR.038
}

\section{Keywords: \\ Erwinia amylovora \\ Cydonia oblonga \\ MARYBLYT \\ forecast \\ epidemic}

\section{Article history:}

Received 15 May 2020

Revised 20 May 2020

Accepted 25 May 2020

\begin{abstract}
Erwinia amylovora is known since 1996 in Hungary, it is the most important bacterial disease of fruit crops belonging to subfamily Maloideae, Rosaceae. The pathogen has quarantine status in propagating material production. It is overwintering in cancerous wounds in the woody parts of the host. The diseases progresses in several steps and can lead the total destruction of the plant. Since antibiotics are banned in field use, protection of the crop must be based on prevention. Symptom appearance and pest occurrence data were collected in 2011 and 2013 in a quince orchard in Lajosmizse, Hungary. Simultaneously weather data and plant phenology were entered in MARYBLYT 4.3 program and results were compared. Based on the results properly parameterized MARYBLYT can be used to forecast fire blight in quince.
\end{abstract}

\section{Introduction}

Quince (Cydonia oblonga Mill.) is an important fruit bearing crop in Hungary. The estimated growing area was around 150 ha in 2014 [21]. Majority of the plantations are near Siófok, Kecskemét and Szeged, where processing facilities and export companies are located. Quince is a versatile fruit [18], it can be eaten raw, cooked for soup, preserved as compote or Membrillo, processed for juice, pulp, pectin or fermented to beer, cider or brandy. The fruit is mainly exported to Germany for further processing or fermentation.

It is the member of Maloideae subfamily, so the essentials of its pest management are basically the same as for apple or pear [18].

Fire blight is one of the most important diseases of pome fruits and ornamentals [1]. Its causative agent is Erwinia amylovora BURR. (WINSLOW) - a bacterium - which was first found and reported in Hungary from Nyárlörinc at the $25^{\text {th }}$ of April 1996 from two neighboring apple orchards [6]. MÁRIA HEVESI published her findings of the first report of the pathogen in 1996 [12]. At the time the authorities tried to eradicate the pest by cutting down and burning the affected orchards and all the host plants in the $3 \mathrm{~km}$ wide zone of the orchards [6]. Despite the strict quarantine measures the disease occurred in 297 more sites in 1996 at a total of 242 ha [7]. In 1997 the disease spread further to a total of 1195 ha, which devastated both growers and hobby gardeners [8]. Plant pathologist assumed at the time - because of the sudden explosion-like spread of the disease - that the pathogen was carried in and distributed with the dirty secateurs of migrant workers from neighboring countries where the disease was already present. Today the pathogen is widespread in the country, and it has been identified from almost all countries where apple is grown (Figure 1.) [5].

Corresponding author. Tel.: +36 76 517-726

E-mail address: agoston.janos@kvk.uni-neumann.hu 


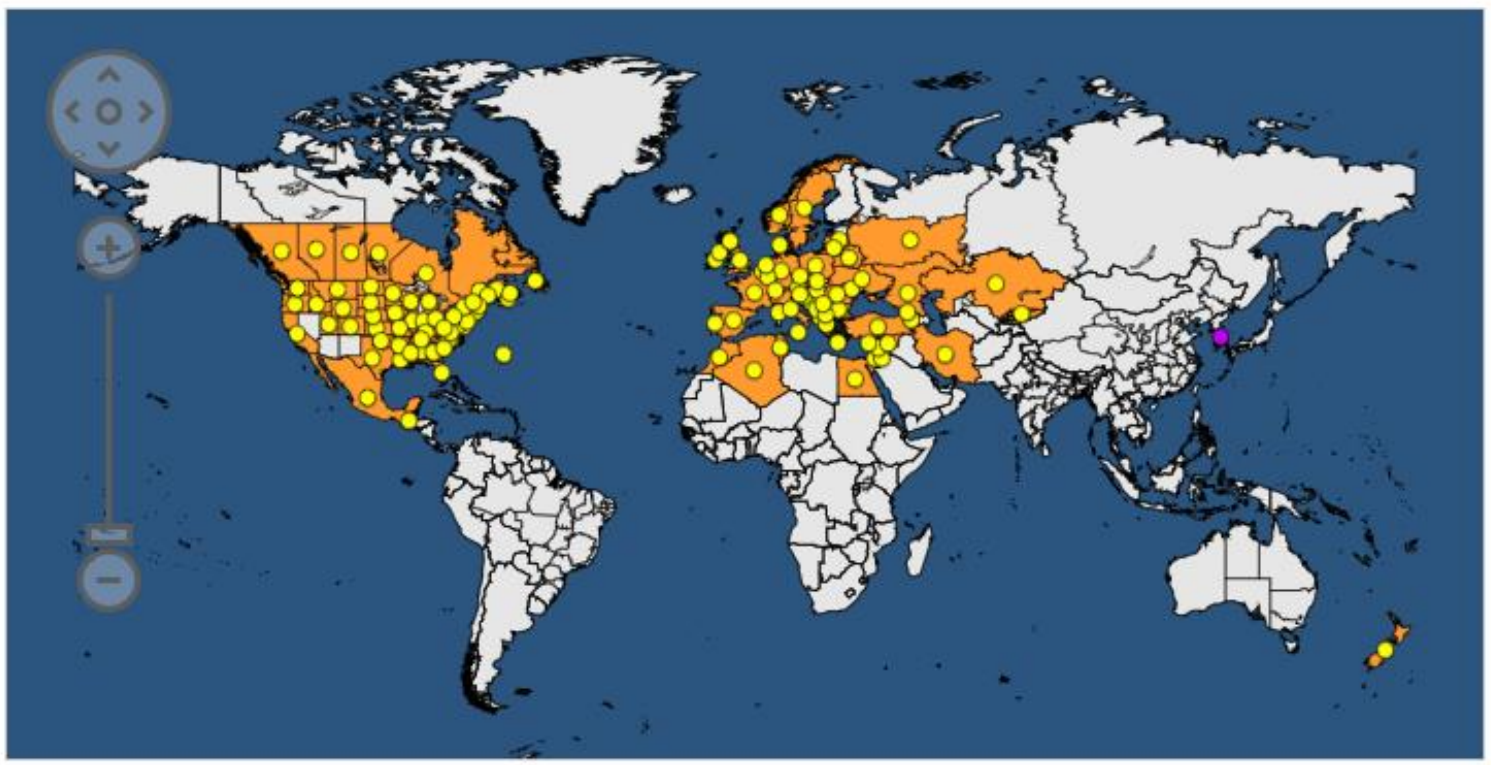

Figure 1. Distribution map of Erwinia amylovora

(Image downloaded from: https://gd.eppo.int/taxon/ERWIAM/distribution, 2020-04-10)

Erwinia amylovora today is still a quarantine pathogen of pome fruit and ornamental propagating material [26] in Hungary, it is on the A2 list of quarantine pests in the EPPO region. In fruit producing orchards it is a Regulated Non-Quarantine Pest (RNQP), which means growers must protect their crop against the disease and prevent its dispersal [5, 26].

The pathogen is a Gram-negative, facultative anaerobe bacterium with no pectolytic properties $[1,11]$. It has a wide range of host plants. According to FLECK it causes diseases on 174 different species of plants [9]. The bacterium infects mainly Maloideae hosts, but lately it has been described from stone fruits (Prunoideae) [24, 25] and from Rosoideae [22]. Important hosts from a horticultural and forestry point of view includes: Amelanchier ovalis, Armeniaca vulgaris, Aronia melanocarpa, Cerasus avium, Chaenomeles spp., Cotoneaster spp., Crataegus spp., Cydonia oblonga, Eryobotria spp., Fragaria spp., Malus spp., Mespilus germanica, Photinia spp., Prunus domestica, Prunus serrulata, Prunus triloba, Pyracantha spp., Pyrus spp., Raphiolepis spp., Rubus spp., Sorbus spp., Spiraea spp. and Stranvaesia spp. [2, 5, 13].

Host plants are infected systemically, causing tracheobacteriosis, a sudden necrosis of foliage, flowers and fruits. Infection can occur in several phenology phases, mostly it starts as an infection of flowers. The bacterium multiplies in the intercellular space, which later causes the typical "shepherd's crook" symptom of young shoots. As the bacterium progresses downwards it causes branch-, trunk- and root collar canker. Fruit rot occurs seldom. Cancerous wounds play a major role of the overwintering of the pathogen [1, 9, 10,13,23]. The main fruit bearing crops can be ranked by susceptibility of fire blight in the following ascending order: apple (Malus domestica Borkh.), pear (Pyrus communis L.), quince (Cydonia oblonga Mill.), medlar (Mespilus germanica L.). This is more or less the order in which the trees flower in spring. While pear appears to flower at the same time or earlier than apple, the flowers of pear are open almost $50 \%$ longer, making it more susceptible. Medlar is considered extremely susceptible, as under Hungarian conditions it flowers in the period from beginning to mid-May, which also coincides with more precipitation.

Resistance genes present in the apple gene pool are hard to combine with traditional breeding techniques to maintain good appearance, tasty fruits with good shelf life and good storing abilities. Commonly used dwarfing rootstocks (like M9, M26) are also very susceptible to the pathogen. According to US research after an epidemic year - where the vast majority of flowers and spurs destroyed - the orchard needs 4 years to fully recover [9]. 
There are several methods to forecast fire blight. Manual forecast is labor intensive, while semi-automated forecast systems only need temperature, precipitation and plant phenology to be entered, examples are COUGARBLIGHT and MARYBLYT $[4,15]$.

MARYBLYT calculates the epiphytic infection potential (EIP), which is an indicator of infection risk, it also gives information of the potential risk ( $\mathrm{L}$ : low, $\mathrm{M}$ : medium, $\mathrm{H}$ : high, I: infection) for infection $[3,14,15,19]$. Generally an EIP of 100 means there is a risk of infection, as a rule of thumb about $10 \%$ of the open flowers may become infected. Besides flower blight, the program can predict the development of other symptoms like shoot-, canker- and trauma blight [20].

\section{Methods}

Investigations were made from 2011 and 2013 at a quince orchard near Lajosmizse. The orchard was planted in 1990, the main grown cultivar was 'Leskovacka', the pollinator partner was 'Vranja', and the rootstock was BA-29 in spacing $6 \times 4$ meters and the trees were trained to bush form.

Fire blight first appeared in 1997 in this orchard, and is present ever since. The orchard has a good general condition with reasonable integrated pest management practices and good fertilizing technology. Infected tree parts are regularly removed and burned. Trees are sprayed regularly with copper salts as a preventive treatment.

The orchard was scouted and assessed in every 2 weeks before flowering for symptoms from beginning of April, at least every 2 days from white petal to petal fall, and at least weekly after petal fall to mid-June. Meteorological data were collected daily (temperature, precipitation), plant phenology was observed at each visit. Meteorological events which may influence infection and symptom development (storm, hail, frost) were also collected.

The trial was set up according to "General test methodology" [16] and each assessment was carried out according to 2.3.4.1.1. point of "Fungicide and bactericide test methodology" [17]. The final assessments were carried out by counting and assessing the total number of disease occurrence of all the branches of 100 trees.

For forecasting and testing MARYBLYT v4.3 was used with settings for pear. Data from the forecast, symptom occurrence and date have been compared.

\section{Results} and 2 .

EIPs over 100 and dates of possible infection predicted by the program are shown in Tables 1

Table 1. EIPs and possible infection days in 2011.

\begin{tabular}{|c|c|c|}
\hline Date & EIP & $\begin{array}{c}\text { Potential } \\
\text { Infection } \\
\text { Risk }\end{array}$ \\
\hline $2011-04-24$ & 121 & high \\
\hline $2011-04-25$ & 121 & medium \\
\hline $2011-04-26$ & 145 & high \\
\hline $2011-04-27$ & 158 & medium \\
\hline $2011-04-28$ & 133 & high \\
\hline $2011-04-29$ & 121 & high \\
\hline $2011-04-30$ & 109 & high \\
\hline $2011-05-01$ & 145 & infection \\
\hline
\end{tabular}


Table 2. EIPs and possible infection days in 2012.

\begin{tabular}{|c|c|c|}
\hline Date & EIP & $\begin{array}{c}\text { Potential } \\
\text { Infection } \\
\text { Risk }\end{array}$ \\
\hline $2013-04-29$ & 121 & high \\
\hline $2013-04-30$ & 218 & high \\
\hline $2013-05-01$ & 364 & high \\
\hline $2013-05-02$ & 461 & high \\
\hline $2013-05-03$ & 448 & infection \\
\hline $2013-05-04$ & 424 & infection \\
\hline $2013-05-05$ & 315 & high \\
\hline $2013-05-06$ & 376 & infection \\
\hline $2013-05-07$ & 339 & infection \\
\hline $2013-05-08$ & 267 & infection \\
\hline $2013-05-09$ & 242 & infection \\
\hline $2013-05-10$ & 242 & high \\
\hline $2013-05-11$ & 230 & high \\
\hline $2013-05-12$ & 218 & infection \\
\hline $2013-05-13$ & 194 & high \\
\hline
\end{tabular}

3.

The predicted and observed dates of blossom-, shoot- and trauma blight are shown in Table

Table 3. Dates of blossom-, shoot- and trauma blight symptoms observed and predicted

\begin{tabular}{|c|c|c|c|c|c|c|}
\hline \multirow{2}{*}{ Year } & \multicolumn{2}{|c|}{ Blossom blight } & \multicolumn{2}{|c|}{ Shoot blight } & \multicolumn{2}{|c|}{ Trauma blight } \\
\hline & observed & predicted & observed & predicted & observed & predicted \\
\hline 2011 & $2011-05-18$ & $2011-05-20$ & $2011-05-26$ & $2011-05-27$ & $n / a$ & $\mathrm{n} / \mathrm{a}$ \\
\hline \multirow{7}{*}{2013} & 2013-05-12 & 2013-05-13 & \multirow{7}{*}{ 2013-06-01 } & \multirow{7}{*}{ 2013-05-31 } & \multirow{7}{*}{$2013-06-13$} & \multirow{7}{*}{ 2013-06-12 } \\
\hline & 2013-05-15 & 2013-05-17 & & & & \\
\hline & 2013-05-17 & 2013-05-19 & & & & \\
\hline & 2013-05-18 & 2013-05-20 & & & & \\
\hline & 2013-05-19 & 2013-05-21 & & & & \\
\hline & $2013-05-20$ & 2013-05-23 & & & & \\
\hline & $2013-05-29$ & 2013-05-30 & & & & \\
\hline
\end{tabular}

In 2011 the disease occurrence was low, only 6 branches were infected in 100 trees at 2011 05-31.

In 2013 the disease occurrence was much higher 2381 branches were infected in 100 trees at 2013-06-13.

\section{Discussion}

In each tested year the MARYBLYT model predicted shoot and blossom blight. Symptoms were observed within \pm 24 to 48 hours to the predicted date. Trauma blight were only observed in 2013 , 
where the model predicted the symptom occurrence 24 hours sooner than the symptom was observed.

\section{Conclusions}

According to the results, MARYBLYT v4.3's prediction was accurate in 48 hour interval, which can be a useful information for the prediction of blossom-, shoot- and trauma blight. This can be a valuable tool for quince growers as formerly no prediction model was available for fire blight in this crop.

\section{Acknowledgment}

l'd like to express my gratitude towards GÁBOR MEZÖ, TAMÁs HEGYI and FERENC KERESZTES for their observations, EDIT SZÜCS and BÁLINT BENEDECZKI for meteorological data, and their help in assessment of the trials and assistance in the laboratory.

Thank you for the support of the research carried out in the framework of the EFOP-3.6.2-162017-00012 „Developing a functional, healthy and safe food product chain model from field to table in a thematic research network". The project is funded by the Hungarian State and the European Union, co-financed by the European Social Fund, and is part of the Széchenyi 2020 program.

\section{References}

[1] Agrios G. N. (2005) Plant pathology. Elsevier Academic press, Amsterdam. ISBN: 978-0-08-047378-9.

[2] Atanasova I., Kabadjova P., Bogatzevska N., Moncheva P. (2005) New host plants of Erwinia amylovora in Bulgaria. Zeitschrift für Naturforschung C 60:893-898. https://doi.org/10.1515/znc-2005-11-1212

[3] Bonn W. G., Leuty T. (1993) An assessment of the MARYBLYT ${ }^{\mathrm{TM}}$ computer program for the prediction of fire blight in Ontario, Canada. Acta Hortic 145-152. https://doi.org/10.17660/ActaHortic.1993.338.20

[4] Dewdney M. M., Biggs A. R., Turechek W. W. (2007) A statistical comparison of the blossom blight forecasts of MARYBLYT and Cougarblight with receiver operating characteristic curve analysis. Phytopathology 97:11641176. https://doi.org/10.1094/PHYTO-97-9-1164

[5] EPPO (2020) EPPO Global Database (available online) https://gd.eppo.int.

[6] EPPO Reporting Service (1996) First report of Erwinia amylovora in Hungary. 1.

[7] EPPO Reporting Service (1997) Situation of fireblight in Hungary in 1996. 1.

[8] EPPO Reporting Service (1998) Situation of fireblight in Hungary in 1997. 1.

[9] Fleck L. M. (2001) Control of fire blight through systemically acquired resistance and intraspecies characterization of Erwinia amylovora. MSc, University of Toronto

[10] Glits M., Folk Gy. (2001) Kertészeti növénykórtan. Mezőgazda Kiadó, Budapest. ISBN: 978-963-286-297-2.

[11] Hauben L., Swings J. (2005) Genus XIII. Erwinia. In: Brenner DJ, Krieg NR, Staley JT, Garrity GM, Boone DR, De Vos P, Goodfellow M, Rainey FA, Schleifer K-H (eds) Bergey's Manual@ of Systematic Bacteriology, 2nd ed. Springer US, Boston, MA. pp. 670-679. ISBN: 978-0-387-24144-9. https://doi.org/10.1007/0-387-28022-7_13

[12] Hevesi M. (1996) Az Erwinia amylovora (Burill) Winslow et al. hazai megjelenése almán. Növényvédelem 32:225-228.

[13] Horst R. K. (ed) (2008) Westcott's Plant Disease Handbook. Springer Netherlands, Dordrecht. ISBN: 978-14020-4584-4. https://doi.org/10.1007/978-1-4020-4585-1

[14] Lightner G. W., Steiner P. W. (1990) Computerization of blossom blight prediction model. Acta Hortic 159-162. https://doi.org/10.17660/ActaHortic.1990.273.20

[15] Lightner G. W., Steiner P. W. (1992) Maryblyt ${ }^{\mathrm{TM}}$ : A computer model for predicting of fire blight disease in apples and pears. Computers and Electronics in Agriculture 7:249-260. https://doi.org/10.1016/S0168-1699(05)800237

[16] MgSzH (2004) Általános vizsgálati módszertan. Mezôgazdasági Szakigazgatási Hivatal, Budapest.

[17] MgSzH (2004) Fungicid és baktericid vizsgálati módszertan. Mezôgazdasági Szakigazgatási Hivatal, Budapest.

[18] Soltész M. (ed) (2001) Integrált gyümölcstermesztés. Mezőgazda Kiadó, Budapest. ISBN: 978-963-9358-31-7.

[19] Steiner P. W. (1990) Predicting apple blossom infections by erwinia amylovora using the MARYBLYT model. Acta Hortic 139-148. https://doi.org/10.17660/ActaHortic.1990.273.18

[20] Steiner P. W. (1990) Predicting canker, shoot and trauma blight phases of apple fire blight epidemics using the MARYBLYT model. Acta Hortic 149-158. https://doi.org/10.17660/ActaHortic.1990.273.19

[21] Szabó T., Nyéki J., Soltész M. (2014) Birs. Újfehértói Gyümölcstermesztési Kutató és Szaktanácsadó Kht., Újfehértó. ISBN: 978-963-12-0940-2.

[22] Vanneste J. L., Lex S., Vermeulen M., Berger F. (2002) Isolation of Erwinia amylovora from blighted plums (Prunus domestica) and potato roses (Rosa rugosa). Acta Hortic 89-94.

https://doi.org/10.17660/ActaHortic.2002.590.10 
[23] Végh A. (2012) Az almafélék tűzelhalásást okozó Erwinia amylovora hazai izolátumainak biológiai változatossága. PhD, Corvinus University of Budapest, Faculty of Horticultural Science, Department of Plant Pathology

[24] Végh A., Némethy Zs., Hajagos L., Palkovics L. (2012) First report of Erwinia amylovora causing fire blight on plum (Prunus domestica) in Hungary. Plant Disease 96:759-759. https://doi.org/10.1094/PDIS-12-11-1013PDN

[25] Végh A., Palkovics L. (2013) First occurence of fire blight on apricot (Prunus armeniaca) in Hungary. Not Bot Hort Agrobot Cluj 41:440. https://doi.org/10.15835/nbha4129183

[26] 7/2001. (I. 17.) FVM rendelet - a növényegészségügyi feladatok végrehajtásának részletesszabályairól. 